Eskişehir Osmangazi Üniversitesi

Sosyal Bilimler Dergisi

Haziran 2020, 21(1), 21-39

DOI: 10.17494/ogusbd. 763360

\title{
The Effect of Destination Attachment and It's Antecedents on Destination Loyalty *
}

\author{
O. Can YILMAZDOĞAN, Cihan SEÇiLMiş ${ }^{* *}$
}

\begin{abstract}
The Effect of Destination Attachment and It's Antecedents on Destination Loyalty

Abstract

The aim of the research was to investigate the relationship between destination attractiveness, satisfaction, attachment and destination loyalty from an integrated point of view. For this purpose, the relevant literature has been examined and a model has been developed. In order to test the developed model, domestic tourists who visited Eskişehir between April and May 2017 were reached by convenience sampling method and 389 questionnaires were evaluated. After the analysis, the developed model was tested and statistically significant and positive correlations were found between the variables of destination attractiveness, satisfaction, attachment and destination loyalty. This research defines the antecedents which have an important place in the formation of loyalty and attachment of tourists. Also, the direct and indirect effects of these antecedents on the formation of loyalty are revealed. A series of proposals are presented in the direction of these effects.
\end{abstract}

Keywords: Eskişehir, Destination Attractiveness, Satisfaction, Attachment, Destination Loyalty

Paper Type: Research

\author{
Destinasyon Aidiyeti ve Öncüllerinin Destinasyon \\ Sadakati Üzerindeki Etkisi
}

Özet

Araştırma ile destinasyon çekiciliği, memnuniyet, aidiyet ve destinasyon sadakati arasındaki ilişkileri bütünleşik bir bakış açısıyla araştırmak amaçlamıştır. Bu amaç doğrultusunda, ilgili alanyazın incelenmiş ve alanyazındaki çalışmalardan hareketle bir model geliştirilmiştir. Geliştirilen modeli test edebilmek için Nisan - Mayıs 2017 tarihleri arasında Eskişehir i ziyaret eden yerli turistlere kolayda örnekleme yöntemi ile ulaşılmış ve 389 anket formu değerlendirmeye alınmıştır. Gerçekleştirilen analizler sonrasında geliştirilen model sınanmış ve destinasyon çekiciliği, memnuniyet, aidiyet ve destinasyon sadakati değişkenleri arasında istatistiksel olarak anlamlı ve pozitif yönlü ilişkiler tespit edilmiştir. Bu araştırma ile turistlerin aidiyet ve devamında sadakat oluşumunda önemli yeri olan öncüller tanımlamakta, bu öncüllerin birbirleriyle ve sadakat ile olan ilişkileri ve sadakat oluşumu üzerindeki doğrudan ve dolaylı etkileri ortaya koyulmaktadır. Bu etkiler doğrultusunda alanyazına ve uygulamaya yönelik bir dizi önerme sunulmaktadır.

Anahtar Kelimeler: Eskişehir, Destinasyon Çekiciliği, Memnuniyet, Aidiyet, Destinasyon Sadakati

Makale Türü: Araştırma

\section{Introduction}

*This research has been produced from the doctoral dissertation titled "The Effect of Destination Attachment and It's Antecedents on Destination Loyalty" and has been implemented with the support provided from Eskisehir Osmangazi University BAP within the scope of project coded 2016-1132.

** O. Can YILMAZDOĞAN, Asst. Prof. Dr., Eskisehir Osmangazi University, Faculty of Tourism, cyilmazdogan@ogu.edu.tr, ORCID ID orcid.org/0000-0003-0642-5395, corresponding author. Cihan SEÇiLMiş, Assoc. Prof. Dr., Eskisehir Osmangazi University, Faculty of Tourism, csecilmis@ogu.edu.tr, ORCID ID orcid.org/0000-00016781-0997.

Article Submission Date 14/04/2020

Article Acceptance Date 17/06/2020 
Tourism, as a socio-economic activity, does not emerge by itself. Some destinations are more successful than other destinations in attracting tourists and interacting with destinations through tourist experience. In this context, the identification and analysis of current tourist resources are crucial in determining the potential for destination attractiveness. It is not possible for unattractive and unattainable tourism regions to be regarded as sustainable products (Kozak, Kozak and Kozak, 2009: 41). In this respect, touristic attractions are important determinants of marketing a region as a touristic product and making it a sustainable touristic attraction. However, the attractiveness of destinations affects not only preferences for destinations but also tourist behaviour in general. Considering that the attractiveness of a destination has an impact on tourist behaviour, it is possible to say that the destinations that include more attractive elements are more likely to be elected and re-visited than other destinations.

The sources of attractiveness are not only dependent on the features that exist in themselves, but also on the perceptions of tourists about these attractions (Garbea, 2014). In this context, it can be said that while there may be a wide variety of attractiveness elements forming a destination, tourists will evaluate the attractiveness of the destination with a holistic view and accordingly evaluate their satisfaction level. It is very important for tourists to appreciate the pleasure of visiting and choosing destination and to understand the tourists' reaction in this context, to improve the products and services of the destination managers and make effective promotions for the target market for the tourists coming back to the destination for the first time or revisiting the destination (Yu and Goulden, 2006).

However, the satisfaction with the destination does not guarantee that the destination will be revisited. Although tourists are highly satisfied with the destination, tourists who are looking for new experiences can turn to different destinations (Croes et al., 2010). The desire to test the untested for these tourists looking for diversity and novelty is an important travel motivation. The desire to recognize new destinations and cultures, and pursue the delights of the unknown may motivate tourists to travel but this may restrict the revisit chance to the same destination and thus the destination loyalty is restricted accordingly (Alegre and Juaneda, 2006). Although satisfaction in this regard is one of the important antecedent of destination loyalty, it may be insufficient to establish loyalty alone.

However, it is stated that visitors who develop attachment to a destination are less likely to change their preferences despite the available alternatives (Yüksel, Yüksel and Bilim, 2010). In this respect, it is stated in recent research that loyalty to a tourism area can affect individual's behaviours including loyalty towards the destination (Brocato, 2006, Campón-Cerro, Alves and HernándezMogollón, 2015). In this context, destination attachment can affect the thoughts and feelings of visitors about the destination and increase the likelihood that people will make positive evaluations regarding destination and remain loyal to the destination. In line with all these evaluations, trying to understand the nature and scope of destination attachment will be helpful in destination planning and destination marketing. 
While numerous studies on loyalty have examined the benefits and practices of loyalty, it may not be possible to say that the number of studies on destination loyalty and the relationship between destination loyalty with other elements is still in an insufficient level. Although there are studies dealing with different variables used in evaluating destination loyalty in the literature, it is seen that the relation setween destination attractiveness, satisfaction, attachment and destination loyalty have not been examined adequately in the relevant literature. The purpose of the research in this context is; to examine the relationship between destination attractiveness, satisfaction, attachment and destination loyalty through an integrated point of view.

Investigation of the subject variables that are thought to be influential on destination loyalty, evaluation of destination loyalty from a holistic point of view and understanding of factors that affect the loyalty of visitors are all important with regards to their contributions to the development of the strategies for the continuation of new visits to the destination and repeated visits to the destination. From this point of view, the research contributes suggesting a new integrated model that can shed light on the relationship between related variables.

\section{Literature Review}

Um, Chon and Ro (2006) investigated the antecedents of revisit intentions for a destination. In this context, the researchers examined the relationship between perceived attractiveness, perceived service quality, perceived value and satisfaction with the revisit intention. Statistically significant and positive correlations were found between all the variables in the study. In the study conducted on the Hong Kong destination, the researchers stated that the variables related to the intention for a repeat visit were influential and that they were influenced more by the perceived attractiveness of the tourists than the satisfaction level of the tourists. In this respect, destination attractiveness according to the research is related to satisfaction and revisit intention. However, destination attractiveness is one of the most important indicators of revisit intention.

In the study conducted by Owusu-Frimpong et al. (2013), functional types of service quality and satisfaction with destination attractiveness were examined. Focusing on the various effects of destination characteristics and demographic variables in the study, it was searched how Ghana's service quality and potential attractiveness could be improved in the selection of destinations for

tourists. It was found in the study that the perceived quality of service and attractiveness of the destination affected customer satisfaction and their repeat intentions.

In the study of Bezirgan and Koç (2014), the effect of local cuisine, which is stated as an important element of attractiveness, on the formation of attachment to the destination was investigated. According to the findings of the study conducted in Cunda Island; there is a statistically significant and positive correlation between the destination attachment and local cuisine. In another study, Cheng, Wuand Huang (2013) examined the relationships between the perceptions of tourists visiting the Penghu Island on destination attractiveness, destination attachment and the environment-responsible behaviour tendency. In the study, it was found out that the greater the attractiveness of the destination perceived by tourists visiting the island, the greater the attachment 
to the island. Furthermore, perceived destination attractiveness and the attachment were found to have an influence on the responsible behaviour towards the environment.

Ramkisson, Smith and Kneebone (2014) examined the relationships between the satisfaction of visitors visiting the Bruce Peninsula National Park in Canada and their attachment to the park. Study findings indicate that visitor satisfaction has a direct influence on the formation of attachment to the national park. In this respect, as the satisfaction of visiting the national park increases, visitors' attachment to the national park also increases.

Eusébio and Vieira (2013) studied the local and foreign tourists in Portugal and examined the relationship between destination attraction, satisfaction and loyalty. Researchers have found a positive and strong relationship between the attractiveness of the destination and the satisfaction and loyalty to the destination.

Um, Chon and Ro (2006) questioned the mediating role of satisfaction between destination attractiveness and revisit intention. Researchers did not find out any significant mediator effect between satisfaction, destination attractiveness, and revisit intention. However, the study by Bigné, Andreu and Gnoth (2005) suggest that satisfaction was mediated by the relationship between positive emotions/evaluations and behavioural intentions. Accordingly, it was assumed that the positive experiences of tourists had a positive influence on the satisfaction evaluations and thus affected their intention to recommend others. In this context, it can be questioned that the relationship between positive perceptions of destination attractiveness and destination loyalty involving behavioural intentions may have mediating effects on satisfaction.

In the light of the findings in the aforementioned literature on the relationship between destination attractiveness and attachment and between the destination attractiveness and the destination loyalty, if the destination attraction causes to attachment and the attachment causes to the destination loyalty, it can be deduced that there is support for the mediation effect of attachment. However, George and George (2004) confirmed that there was a mediating role of the attachment in the relationship between the past visits and repeat visits to the destination.

The following research hypotheses were developed in the study based on the literature review:

$\mathrm{H} 1$ : There is a statistically positive and significant correlation between destination attractiveness and satisfaction.

$\mathrm{H} 2$ : There is a statistically positive and significant correlation between destination attractiveness and attachment.

H3: There is a statistically positive and meaningful correlation between satisfaction and attachment.

H4: There is a statistically positive and significant correlation between destination attractiveness and destination loyalty. 
H5: There is a statistically positive and significant correlation between satisfaction and destination loyalty.

H6: There is a statistically positive and significant correlation between attachment and destination loyalty.

$\mathrm{H7}$ : Attachment has a mediating effect on the relationship between destination attractiveness and destination loyalty.

H8: Satisfaction has a mediating effect on the relationship between destination attractiveness and destination loyalty.

Taking into account all these studies mentioned in the literature, the model of the research was constructed as in Figure 1.

Figure 1. Proposed Research Model

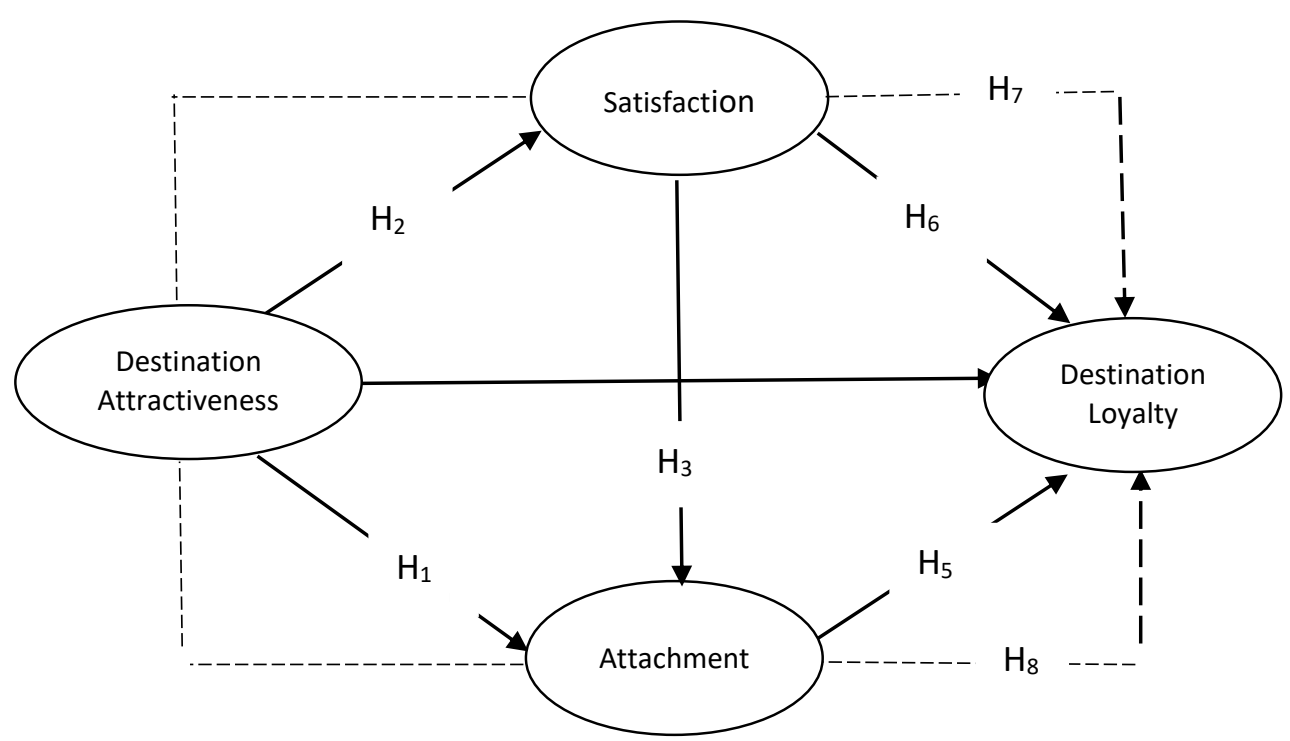

After constructing a research model in the direction of the findings of the studies in the relevant literature, the process of creating the data collection tool was started to test the research model. 


\section{Methodology}

\section{1. Measurements}

In order to determine the perceived attractiveness of the local tourists visiting Eskişehir destination, the scale of the destination attractiveness developed by Hou, Lin and Morais (2005) which proved its reliability and validity in a large number of researches was used in the research. At this scale, the perceived attractiveness of tourists for the destination was classified in 5 dimensions by 17 items. From these dimensions; there were 6 items for measuring "Tourism Services", 3 items for measuring "Cultural Attraction", 2 items for measuring "Events", 3 items for measuring "Interpretation", 3 items for measuring "Peripheral Attractions" form.

The survey utilized the items used by Yüksel, Yüksel and Bilim (2010) to measure the satisfaction with the destination in order to determine the satisfaction of the local tourists visiting Eskişehir. According to this, the satisfaction perceptions of tourists towards the destination were evaluated with 3 expressions under one dimension.

Destination attachment was measured by 12 items, which were found to have good internal consistency with previous studies and were generally accepted in the relevant literature. The two dimensions in which identity was often assessed are "Place Identity" and "Place Dependence". It was observed that some studies attempted to measure destination attachment by making different additions to these dimensions. However, in the measure of destination attachment, these two dimensions were considered as the basis. In this context, the research benefited from these two basic dimensions. The statements that Williams and Vaske (2003) used in their study were adapted to Eskişehir and the expressions were created in the form of 5-point Likert-type scaling (1: strongly disagree, 5: strongly agree).

In the study, the three-dimensional measurement model which was used by Yüksel, Yüksel and Bilim (2010) was used in measuring the destination loyalty. Out of these dimensions, "Cognitive Loyalty" includes 3 expressions and "Affective Loyalty" includes 3 expressions, and finally "Conative Loyalty" includes 2 expressions. The statements that Yüksel, Yüksel and Bilim (2010) used in their study and tested them in the case of Didim were adapted for the case of Eskişehir.

\section{2. Sample and Data Collection}

Approximately 92.5\% of the tourists visiting Eskişehir were domestic tourists (Turkish Statistical Institute [TUIK], 2017) and because Eskişehir was one of the main attractions of domestic tourism, the study focused on the local tourists who visited Eskişehir. In this context, the population of the research is all domestic tourists visiting Eskişehir. Since all the tourists visiting Eskişehir cannot be reached because of time and cost related constraints, the reachable research population whose time and place concepts were determined, constituted the domestic tourists visiting Eskişehir between April and May 2017.

The pre-test was conducted in order to test the comprehensibility of the expressions in the questionnaire form under real conditions and to obtain preliminary information about whether the 
expected results could be reached after the application of the questionnaire (Oppenheim, 1966). A pre-test was conducted in March 2017 with 100 people who visited Eskişehir and who were chosen by convenience sampling method. As a result of the pre-test, the Cronbach Alpha $(\alpha)$ coefficient was calculated as 0,926 for all Likert-type expressions in the questionnaire. Since there were no expressions which significantly increased the reliability with the removal of these scales, no changes were made in the statements and the questionnaire was finalized.

In the study, face-to-face questionnaire was applied to those who accepted to fill in the questionnaire form which was determined by convenience sampling method in Odunpazarı, Adalar regions and themed parks, which were mostly preferred by the group tourists and individual tourists who visited Eskişehir. Between April and May 2017, a total of 400 people were reached. 11 questionnaires that were found to be incomplete or incorrectly filled were not included in the analysis and 389 questionnaire forms were evaluated. The data collection process of the research was carried out before 2020. Ethics committee permit is not included for this reason.

In the study, a reliability analysis was performed through the SPSS 22.0 package program to test the consistency and reliability of the scale and measurement. Cronbach Alpha coefficient was examined by reliability analysis and the overall reliability of the measurement was found as 0.957. In addition, the Cronbach Alpha values of each scale used in the study are given in Table 1.

Table 1. Reliability Analysis Results

\begin{tabular}{ll}
\hline \hline Scale & Cronbach Alpha $(\boldsymbol{\alpha})$ Value \\
\hline Destination Attractiveness & 0.875 \\
Satisfaction & 0.863 \\
Attachment & 0.944 \\
Destination Loyalty & 0.917 \\
\hline
\end{tabular}

\section{3. Data Analysis}

Data analysis was performed in three steps. First, SPSS (Statistical Package for Social Sciences) 22.0 program was chosen for the analysis of the data set, the calculation of the frequency distributions for demographic information, and the mean of the factor dimensions and subdimensions for the relevant variables. In the next step, confirmatory factor analysis was performed to test the appropriateness of the measurement model and to determine the extent to which the structures in the model were represented by the measured variables. In the last step, LISREL 8.80 was used to test the structural equation modeling by testing the relationships between destination attractiveness, satisfaction, attachment and destination loyalty. 


\section{Results}

Most of the participants (59.1\%) appear to be in the 16-34 age range. According to this; it can be said that a relatively young tourists visited Eskişehir more frequently. When the educational status of domestic tourists visiting Eskişehir was examined, it was understood that a large part of the participants $(61.1 \%)$ are composed of people who have completed university education at various levels. In addition, considering the high proportion of young people among the visitors, it can be thought that there are those who continue their undergraduate education. In this respect, it can be said that the visits to Eskişehir are mostly composed of educated people. However, the gender rates of visitors; $51.2 \%$ female and $48.8 \%$ male are very close to each other.

When the frequencies of visitors to Eskişehir are examined, 118 people (30.3\%) visited Eskişehir for the first time. It is understood that the remaining $69.7 \%$ have revisited Eskişehir. However, it is observed that the repeat visit rate of Eskişehir decreased after 2-4 visits. Visits are mostly (82.5\%) accompanied by one or more persons.

When the accommodation frequencies and types of the participants were observed, it was understood that they mostly visited on a daily basis (30.4\%) or stay for 1-2 nights (29.3\%). According to these findings, the participants preferred to overnight in Eskisehir (69.6\%). However, those staying overnight in Eskişehir were in great proportion (59.4\%) preferred to stay at the family, relatives' or friend's house.

It is observed that those who do not stay in family, relatives or friends' homes usually prioritize 3-4 star hotels or pensions. The least preferred options during the stay were found to be camping (1.1\%) and 2-star hotels (0.3\%). It was also clear that those who visited Eskişehir did not reside in Eskişehir (83.5\%) before and those who previously resided in Eskişehir (16.5\%) prefer revisits to Eskişehir. 
Figure 2. Confirmatory Factor Analysis and Standardized Analysis Values

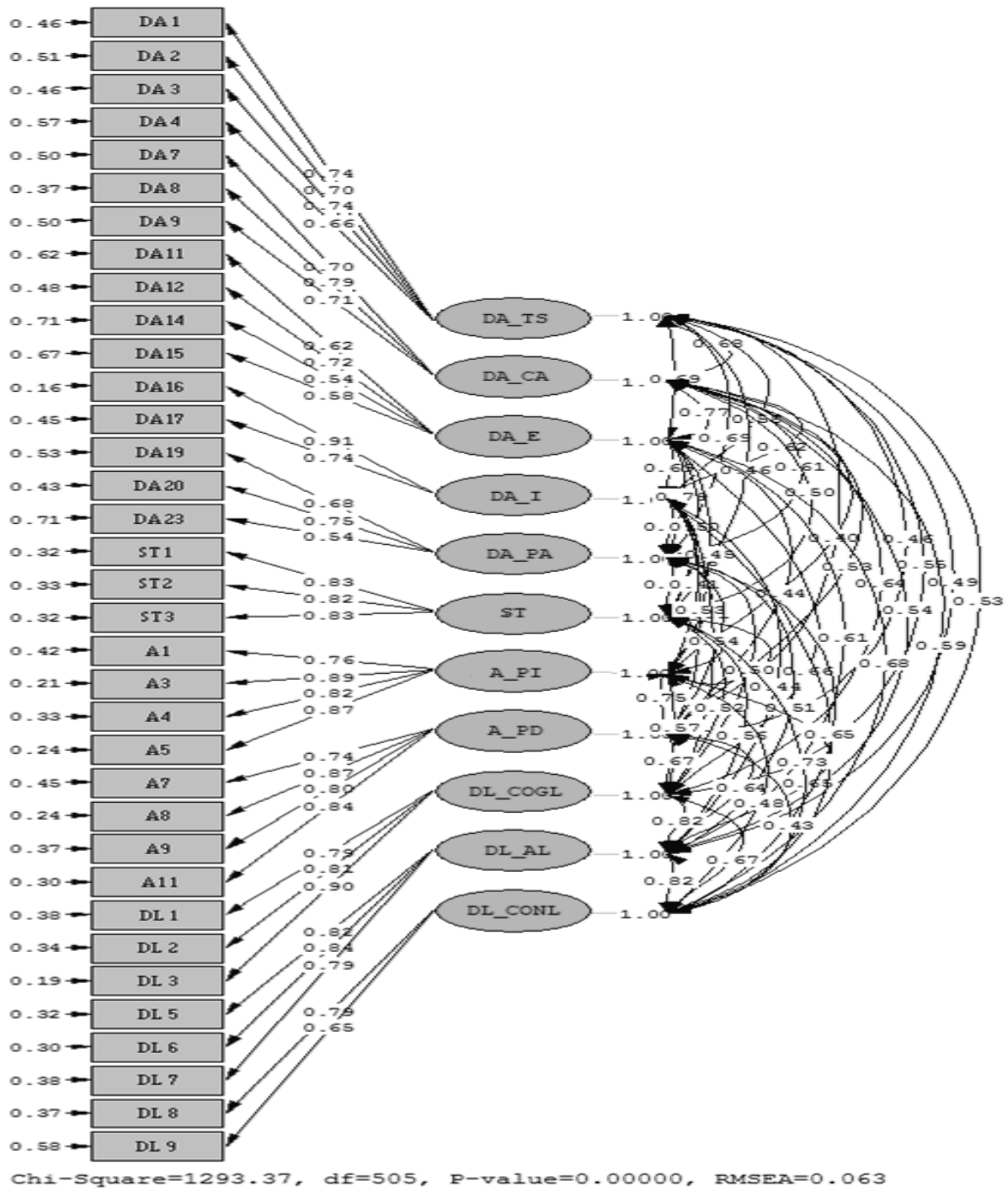

Confirmatory factor analysis (CFA) is a natural extension of explanatory factor analysis, and it is used especially in assessing the relationships between latent variables and observed variables (Çelik and YIlmaz, 2016). It was examined whether multivariate normality was obtained before the analysis of the data. Multivariable normality was evaluated through LISREL and the result was that 
the data were not normally distributed. In this regard, the "Robust Maximum Likelihood" parameter estimation method was utilized in the research. As a result of confirmatory factor analysis, some standardized analysis values and t-values were found not to be in the desired level should be extracted (Çelik and Yılmaz, 2016) and therefore, they were extracted in the analysis. Accordingly, on the scale of destination attractiveness, the DA10 under the cultural attractiveness factor and the DA20 item under the environmental attractiveness factor were removed. Satisfaction was measured by three expressions and one factor, and no problems were encountered with this measurement. On the other hand; in the attachment scale, the items A2 and A6 which are under the place identity and A10 under the dimension of place dependence were excluded in the study as they affected the standardized resolution values negatively. In the destination loyalty scale, the DL4 item under the cognitive loyalty dimension was excluded in the study and the measurement model was formed at an acceptable level. The measurement model obtained in line with these studies is shown in Figure 2 and the comparison of the proposed compliance values for the model and the standard compliance measures are given in Table 2.

Table 2. Compliance Values and Standard Compliance Criteria for Measurement

\begin{tabular}{cccc}
\hline Compliance Values & Good Fit* & Acceptable Fit** & Model \\
\hline RMSEA & $0 \leq \mathrm{RMSEA} \leq 0.05$ & $0.05 \leq \mathrm{RMSEA} \leq 0.10$ & $\mathbf{0 . 0 6 3} *$ \\
NFI & $0.95 \leq \mathrm{NFI} \leq 1$ & $0.90 \leq \mathrm{NFI} \leq 0.95$ & $\mathbf{0 . 9 6}$ \\
NNFI & $0.97 \leq \mathrm{NNFI} \leq 1$ & $0.95 \leq \mathrm{NNFI} \leq 0.97$ & $\mathbf{0 . 9 7}$ \\
IFI & $0.95 \leq \mathrm{IFI} \leq 1$ & $0.90 \leq \mathrm{IFI} \leq 0.95$ & $\mathbf{0 . 9 8}$ \\
RFI & $0.95 \leq \mathrm{RFI} \leq 1$ & $0.90 \leq \mathrm{RFI} \leq 0.95$ & $\mathbf{0 . 9 5}$ \\
CFI & $0.97 \leq \mathrm{CFI} \leq 1$ & $0.95 \leq \mathrm{CFI} \leq 0.97$ & $\mathbf{0 . 9 7}$ \\
GFI & $0.95 \leq \mathrm{GFI} \leq 1$ & $0.90 \leq \mathrm{GFI} \leq 0.95$ & $\mathbf{0 . 8 4}$ \\
AGFI & $0.90 \leq \mathrm{AGFI} \leq 1$ & $0.85 \leq \mathrm{AGFI} \leq 0.90$ & $\mathbf{0 . 8 0}$ \\
$\left(\chi^{2} /\right.$ s.d. $)$ & $<\mathbf{2}$ & $<\mathbf{5}$ & $\mathbf{2 . 4 5 4 *}$
\end{tabular}

References: Jöreskog and Sörbom, 1996; Schermelleh-Engel, Moosbrugger and Müller, 2003; Schumacker and Lomax, 2004.

When the values of the measurement model and standard compliance fit measures in Table 16 were examined, the ratio of $\chi 2$ to the degree of freedom was approximately 2.45 , which indicates acceptable compliance adaptability. The RMSEA value is also 0.06 and has an acceptable value. NFI, $\mathrm{NNFI}, \mathrm{IFI}, \mathrm{RFI}$ and CFI values were found to be quite good. However, the GFI value was 0.84 and the AGFI value was 0.80 were found to be below the acceptable value. This can be justified by the sample size which is 389 people. Because GFI and AGFI have a structure that is likely to be influenced by the sample size (Kline, 2011). It can be suggested that the goodness of fit index values is high, 
looking at the evaluation of the nine different goodness of fit indexes. Therefore, after these stages, the structural model was formed and the relations between the variables were tested.

The proposed SEM diagram of the model created by the LISREL program is seen in Figure 3. When the model was tested, it was understood that DA, which was an external variable, significantly predicted all internal variables. There is a significant (0.54) relationship between DA and ST in the positive direction. Significant and positive correlations were also found between DA and A $(0.55)$ and DL (0.35).

Figure 3. Model's SEM Diagram (LISREL v8.80)

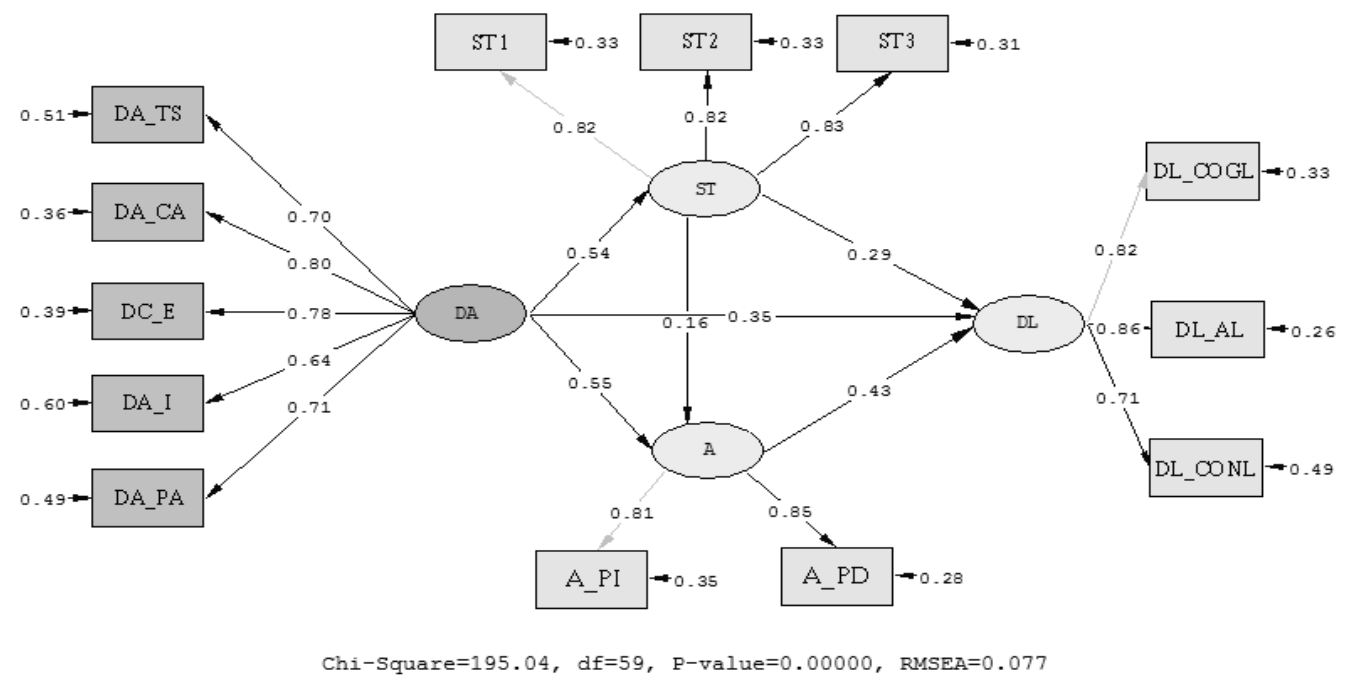

The ST internal variable had significant positive correlations with both the A internal variable (0.16) and the DL internal variable (0.29). However, there is a positive and significant $(0.43)$ relationship between $A$ internal variable and $D L$ internal variable. The result of the analysis showed that all the variables in the model had meaningful relationships with each other and that all parameter values of the models in the model had values less than 1 and all the $t$-values appeared above the theoretical value of 1.96 and thus the relations suggested as research hypotheses can be accepted. The parameter values, $t$ values and other adjustment statistics for the variables in the model are given in Table 3 and Table 4. 
Eskişehir Osmangazi Üniversitesi Sosyal Bilimler Dergisi

Table 3. SEM Results for Research Model

\begin{tabular}{|c|c|c|c|c|c|c|}
\hline Factors / Items & $\begin{array}{l}\text { Standart } \\
\text { Loads }\end{array}$ & t-value & $R^{2}$ & $C R$ & AVE & $\begin{array}{l}\alpha \\
(C A)\end{array}$ \\
\hline DA: Destination & & & & 0.85 & 0.53 & 0.838 \\
\hline \multicolumn{7}{|l|}{ Attractiveness } \\
\hline DA_F1: Tourism Services & 0.70 & $15.07 * * *$ & 0.49 & & & \\
\hline$D A \_F 2:$ Cultural Attraction & 0.80 & $18.16^{* * *}$ & 0.64 & & & \\
\hline$D A \_F 3:$ Events & 0.78 & $17.44^{* * *}$ & 0.61 & & & \\
\hline \multicolumn{7}{|l|}{ DA_F4: Interpretation } \\
\hline $\begin{array}{ll}D A \_F 5: & \text { Peripheral } \\
\text { Attractions } & \end{array}$ & 0.71 & $15.34 * * *$ & 0.50 & & & \\
\hline ST: Satisfaction & & & & 0.86 & 0.68 & 0.863 \\
\hline $\begin{array}{l}\text { ST_1: I am happy about my } \\
\text { decision to visit Eskisehir }\end{array}$ & 0.82 & & 0.67 & & & \\
\hline \multicolumn{7}{|l|}{ ST_2: I believe I did the } \\
\hline $\begin{array}{l}\text { right thing when I chose to } \\
\text { make my visit to Eskisehir }\end{array}$ & 0.82 & $17.14^{* * *}$ & 0.67 & & & \\
\hline $\begin{array}{l}S T_{-} 3 \text { : Overall, I am satisfied } \\
\text { with decision to make my } \\
\text { visit to Eskisehir. }\end{array}$ & 0.83 & $17.38 * * *$ & 0.69 & & & \\
\hline A: Attachment & & & & 0.81 & 0.69 & 0.811 \\
\hline A_F1: Place Identity & 0.81 & & 0.66 & & & \\
\hline A_F2: Place Dependence & 0.85 & $15.14 * * *$ & 0.72 & & & \\
\hline \multicolumn{4}{|l|}{$\overline{D L}$ : Destination Loyalty } & 0.84 & 0.64 & 0.831 \\
\hline DL_F1: Cognitive Loyalty & 0.82 & & 0.67 & & & \\
\hline$D L \_F 2$ : Affective Loyalty & 0.86 & $18.99 * * *$ & 0.74 & & & \\
\hline DL_F3: Conative Loyalty & 0.71 & $15.00 * * *$ & 0.50 & & & \\
\hline \multicolumn{3}{|l|}{ Hypotheses } & Result & & & \\
\hline$H_{1}: D A \rightarrow S T$ & 0.54 & $9.37 * * *$ & Accepted & & & \\
\hline$H_{2}: D A \rightarrow A$ & 0.55 & $8.01 * * *$ & Accepted & & & \\
\hline$H_{3}: S T \rightarrow A$ & 0.16 & $2.46^{* *}$ & Accepted & & & \\
\hline$H_{4}: D A \rightarrow D L$ & 0.35 & $5.93 * * *$ & Accepted & & & \\
\hline$H_{5}: S T \rightarrow D L$ & 0.29 & $5.94 * * *$ & Accepted & & & \\
\hline$H_{6}: A \rightarrow D L$ & 0.43 & $7.34 * * *$ & Accepted & & & \\
\hline \multicolumn{7}{|l|}{$\mathrm{ST}=0.54^{*} \mathrm{DA}, \mathrm{R}^{2}=0.29$} \\
\hline \multicolumn{7}{|c|}{$A=0.16 * S T+0.55^{*} D A, R^{2}=0.42$} \\
\hline \multicolumn{7}{|c|}{$\mathrm{DL}=0.29 * \mathrm{ST}+0.43 * \mathrm{~A}+0.35 * \mathrm{DA}, \mathrm{R}^{2}=0.81$} \\
\hline
\end{tabular}

Destination attractiveness explains $29 \%$ of the satisfaction variable $\left(R^{2}: 0.29\right)$. Destination attractiveness and satisfaction variables account for $42 \%$ of the loyalty variable ( $\left.R^{2}: 0.42\right)$. Destination attractiveness, satisfaction and attachment variables together explained the $81 \%$ of the destination loyalty ( $\left.R^{2}: 0.81\right)$. When the values of the model mentioned in Table 3 were examined, 
it was seen that all the values were within sufficient limits. According to this; six hypotheses were used to explain the relationship between the variables in the model and they were accepted according to the related values. The compliance values for the proposed model and the standard compliance measures are given in Table 4.

Table 4. Fit Values of Proposed Model and Standard Compliance Criteria Values

\begin{tabular}{lccl}
\hline \hline Compliance Mesures & Good Fit & Acceptable Fit** & Model \\
\hline RMSEA & $0 \leq \mathrm{RMSEA} \leq 0.05$ & $0,05 \leq \mathrm{RMSEA} \leq 1$ & $\mathbf{0 . 0 7 7 ^ { * * }}$ \\
NFI & $0.95 \leq \mathrm{NFI} \leq 1$ & $0.90 \leq \mathrm{NFI} \leq 0.95$ & $\mathbf{0 . 9 7}^{*}$ \\
NNFI & $0.97 \leq \mathrm{NNFI} \leq 1$ & $0.95 \leq \mathrm{NNFI} \leq 0.97$ & $\mathbf{0 . 9 7}$ \\
IFI & $0.95 \leq \mathrm{IFI} \leq 1$ & $0.90 \leq \mathrm{IFI} \leq 0.95$ & $\mathbf{0 . 9 8}$ \\
RFI & $0.95 \leq \mathrm{RFI} \leq 1$ & $0.90 \leq \mathrm{RFI} \leq 0.95$ & $\mathbf{0 . 9 6}$ \\
CFI & $0.97 \leq \mathrm{CFI} \leq 1$ & $0.95 \leq \mathrm{CFI} \leq 0.97$ & $\mathbf{0 . 9 8}$ \\
GFI & $0.95 \leq \mathrm{GFI} \leq 1$ & $0.90 \leq \mathrm{GFI} \leq 0.95$ & $\mathbf{0 . 9 3}$ \\
AGFI & $0.90 \leq \mathrm{AGFI} \leq 1$ & $0.85 \leq \mathrm{AGFI} \leq 0.90$ & $\mathbf{0 . 8 9 * *}$ \\
$\left(\chi^{2} /\right.$ s.d. $)$ & $<\mathbf{2}$ & $\mathbf{3 . 3 0 6 * *}$ \\
\hline
\end{tabular}

When the fit values of the proposed model are examined, it can be suggested that it is a model that conforms to the standard compliance criteria values. When the values in Table 4 were examined, RMSEA, GFI, AGFI and X2/s.d. values appeared to be in the range of acceptable fit. However, it was understood that all other compliance measures apart from the mentioned compliance measures had a good fit. When all findings related to the research model were evaluated, it could be suggested that the theoretical model was a statistically significant model.

\section{Evaluation of Mediating Effect}

There are many statistical methods such as hierarchical regression (Baron and Kenny, 1986) and Structural Equation Modelling (SEM) which test mediation effect (Hair, et al., 2010). Ro (2012) stated that among the 572 peer-reviewed articles in the International Journal of Hospitality Management (IJHM), 75 percent of the mediation hypotheses were tested with SEM, and this was found to be a frequently used method. In this context, the mediation effects in the structural model were evaluated through the SEM. Accordingly, the following hypotheses will be tested by assessing the mediating effects:

$\mathrm{H7}$ : Attachment has a mediating effect on the relationship between destination attractiveness and destination loyalty.

H8: Satisfaction has a mediating effect on the relationship between destination attractiveness and destination loyalty. 
In the research, firstly, the mediation role of satisfaction (ST) between Destination Attractiveness (DA) as an independent variable and Destination Loyalty (DL) as the dependent variable was evaluated. In the study, firstly the preconditions of relations between variables were evaluated and it was examined whether the paths in these conditions were meaningful. Accordingly, it was found out that there was a significant relationship between DA and DL at 0.78 level. It was then assessed whether DL predicted ST significantly. According to this evaluation; there was a significant relationship between $\mathrm{DL}$ and $\mathrm{ST}$, and the level of this relationship was 0.54 (X2: $44.48, \mathrm{df}: 19, \mathrm{p}=0.00081, \mathrm{RMSEA}=0.059$ ). Afterwards, a path analysis was performed to determine whether DA and ST were predictors and DL was a predictor variable. It was understood that the way drawn from DL to DA was meaningful, but with the inclusion of ST into the model, it was understood that the coefficient of correlation between DL and DA variables decreased from 0.78 to 0.58 . Accordingly, the partial mediating effect of ST in the relationship between DA and DL can be mentioned. According to this determination, $\mathrm{H} 7$ was accepted.

After the determination of the partial mediation of the ST between the DA and the DL, the relationship between the DA and the DL was investigated through the $A$. Since the existence of significant relationships between DA and DL was accepted as a prerequisite, the relationship between DA and A was analysed. According to this; a significant correlation between DA and A was found at 0.64 level. Afterwards, a path analysis was performed to determine whether DA and A were predictors and DL was a predicted variable. It was seen that the path drawn from DA to DL was meaningful, with the inclusion of $A$ into the model, it was seen that the correlation coefficient between DA and DL variables decreased from 0.78 to 0.48 . Accordingly, the partial mediating effect of $A$ on the relationship between DA and DL could be mentioned. According to this determination, $\mathrm{H} 8$ was accepted. The results of the study and suggestions were given based on the findings of the research.

\section{Discussion and Conclusions}

This research identifies the antecedents, which have an important role in the place attachment and loyalty formation of the tourists. It offers a series of propositions between each other and their relationship with loyalty and their direct and indirect effects on loyalty formation. According to this, in the relations between attachment and its antecedents, attachment to the destination is assumed to be one of the most effective elements $(0.43)$ driving the loyalty of destination. Furthermore, satisfaction with destination (0.29) and perceived attractiveness $(0.35)$ were found to have an impact on destination loyalty. In addition to these relationships, satisfaction and destination attachment directly and indirectly affect destination loyalty. One of the most significant theoretical contribution of this study is to propose a model in which empirical validation of these relations is handled in a single model by evaluating the antecedents and the relations between these antecedents in the formation of destination loyalty.

Similar to the findings of other studies carried out in different destinations, current, it is supported that attachment has a positive effect on loyalty (Alexandris, Kouthouris and Meligdis, 
2006; Prayag and Ryan, 2012; Yüksel, Yüksel and Bilim, 2010). According to the findings of the study, significant correlations were found between destination attractiveness and attachment. In this respect, similar to previous studies, the findings of the current study support that visitors feel attachment to destinations through attractiveness. (Bezirgan and Koç, 2014; Cheng, Wu and Huang, 2013; Reitsamer, Brunner-Sperdin and Stokburger-Sauer, 2016). Therefore, these findings support the proposition of Stedman (2003); destination can retain its visitors with its attractiveness and strong emotional links with its visitors.

Literature suggest that the positive experiences of the tourists on the tourism products and the attractiveness of the destination affect the satisfaction positively (Chi and Qu, 2008; Hui, et al., 2007; Gallarza and Saura, 2006; Matzler, Füller and Faullant, 2007; Owusu-Frimpong et al., 2013; Um, Chon and Ro, 2006) For example, Um, Chon and Ro (2006), in their study on the Hong Kong destination, they stated that the revisit intention was more influenced by the perceived attractiveness than the satisfaction level. Similarly, in this study, it is observed that the attractiveness of the destination (0.35) is more effective on the loyalty of the destination which includes the revisit intention according to the satisfaction (0.29). In other words, it can be said that the loyalty of the destination can be determined by the elements that attract them rather than the ones that satisfy the tourists.

Similar to the relationship between attractiveness and satisfaction, the positive relationship between satisfaction and attachment is not surprising in view of the general acceptance, and this relationship shows that satisfactory experiences about the destination will contribute to attachment as highlighted in various studies in the literature (Bezirgan, 2015; Campón-Cerro, Alves and Hernández-Mogollón, 2015; Halpenny, 2006; Hwang, Lee and Chen, 2005; Prayag and Ryan, 2012; Ramkisson, Smith and Kneebone, 2014; Williams and Vaske, 2003; Yuksel, Yuksel and Bilim, 2010). In this respect; it shows that if tourists are more satisfied with the destination experience, they perceive the destination as more compatible with them and develop attachment to the destination.

The structural path between satisfaction and destination loyalty is consistent with the relevant literature (Chen and Tsai 2007; Chi and Qu 2008; Kozak, Bigné and Andreu, 2005; Kim, 2008; Prayag 2008; Yoon and Uysal, 2005). Therefore, as the level of satisfaction of tourists increases, loyalty towards the destination are increasing. In addition to the direct impacts of satisfaction loyalty in the research, there was also the mediating effect of satisfaction between destination attractiveness and loyalty. In other words, if visitors are happy to see the attractions of the destination, but they are pleased to visit these attractions, this satisfaction strengthens the formation of destination loyalty. In other words, if the visitors perceive the attraction of destination positively and are satisfied to visit these attractions, this satisfaction strengthens the formation of destination loyalty.

When the results of the research are evaluated generally in the direction of the research model, the tourist services offered by the destinations to the tourists, the cultural and environmental attractiveness and the activities organized in the destination and the satisfaction with this attractiveness are the influential factors in the formation of attachment. All these variables together 
have a significant impact on destination loyalty and can be considered among the most important factors that can be used in the formation of destination loyalty.

Beyond the contribution of the structural relationships determined among these variables to the literature, these relations have some important administrative effects. The attractiveness and satisfaction of these attractiveness are important determinants of attachment as stated by Prayag and Ryan (2012). In this regard, investments in tourist services such as public transport, infrastructure and local restaurants are important for place attachment. In addition, it can be said that the efforts to protect and develop the environmental and cultural attractions and to diversify the activities will contribute to the development of attachment to the Eskişehir destination. In this respect, it is useful for decision-makers in Eskişehir destination to use strategies that stimulate, protect and enhance the attachment of the visitors in their destination management plans. However, among the sub-dimensions of destination attractiveness, those with the highest rate for Eskişehir destination are cultural attractions $(0,80)$ and activities $(0,78)$. In this respect, it can be said that destination managers need to protect, diversify and enhance the cultural attractions and activities that attract competitive advantage to Eskişehir.

According to the research findings, destination attractiveness is one of the factors influencing the destination loyalty. At this point, as Bezirgan and Koç (2014) stated; destinations should emphasize their attractiveness and carry out promotional activities necessary to reach the target market. However, the similarity of destinations with other destinations may decrease satisfaction (Yüksel, Yüksel \& Bilim, 2010). In this respect, differentiating attractiveness from other destinations will provide a competitive advantage in terms of satisfaction and loyalty. At this point, as stated by Giritlioğlu and Avcıkurt (2010); while the tourist attractions are differentiated, the quality of all services offered to tourists should be increased.

In addition, destination loyalty that emerged through touristic experience is not only based on a certain attractiveness or service, but also because it has been influenced by many social interactions and chain of events. Research findings shows that by using these qualifications, Eskişehir can strengthen and improve its current position. Attachment is not a feeling that is developed solely for physical elements. Social elements are also important in the formation of attachment (Bezirgan and Koç, 2014). In this context, when physical attractiveness is supported by social elements, attachment will be strengthened.

Tourists evaluate the tourism experience as a whole. This situation shows that things that are evaluated in a holistic manner must be produced and managed in a holistic manner (Mendes et al., 2010; Weiermair, 2000). In other words, managers should consider the perceptions of tourists towards Eskişehir destination and follow all the factors that may affect these perceptions up-todate.

\section{Ethical Approval}

The data collection process of the research was carried out before 2020. Ethics committee permit is not included for this reason. 


\section{Contribution Rates of Authors to the Article}

1st author \%80, 2nd author \%20.

\section{Funding Statement}

This research has been produced from the doctoral dissertation titled "The Effect of Destination Attachment and It's Antecedents on Destination Loyalty" and has been implemented with the support provided from Eskisehir Osmangazi University BAP within the scope of project coded 20161132.

\section{Conflicts of Interest}

On behalf of all authors, the corresponding author states that there is no conflict of interest.

\section{References}

Alegre, J. and Juaneda, C. (2006). Destination Loyalty: Consumers' Economic Behaviour, Annals of Tourism Research, 33, 684-706.

Alexandris, K., Kouthouris, C. and Meligdis, A. (2006). Increasing Customers' Loyalty in a Skiing Resort: The Contribution of Place Attachment and Service Quality, International Journal of Contemporary Hospitality Management, 18(5), 414-425.

Bezirgan, M. and Koç, F. (2014). Yerel Mutfakların Destinasyona Yönelik Aidiyet Oluşumuna Etkisi: Cunda Adası Örneği, Uluslararası Sosyal Araştırmalar Dergisi, 7(34), 917-928.

Bigné, J. E., Andreu, L. and Gnoth, J. (2005). The Theme Park Experience: An Analysis of Pleasure, Arousal and Satisfaction, Tourism Management, 26(6), 833-844.

Brocato, E. D. (2006). Place Attachment: An Investigation of Environments and Outcomes in a Service Context, Texas University, Doctoral Thesis.

Campón-Cerro, A. M., Alves, H. M. B. And Hernández-Mogollón, J. M. (2015). Attachment as a Factor in Generating Satisfaction with, and Loyalty to, Rural Tourism Destinations, Tourism and Management Studies, 11(1), 70-76.

Cheng, T., Wu, H. C. and Huang, L. (2013). The Influence of Place Attachment on the Relationship Between Destination Attractiveness and Environmentally Responsible Behavior for Island Tourism in Penghu, Taiwan, Journal of Sustainable Tourism, 21(8), 1166-1187.

Chi, C. G. and Qu, H. (2008). Examining the Structural Relationships of Destination Image, Tourist Satisfaction and Destination Loyalty: An Integrated Approach, Tourism Management, 29(4), 624-636.

Croes, R., Shani, A. and Walls, A. (2010). The Value of Destination Loyalty: Myth or Reality?, Journal of Hospitality Marketing, 19(2), 115-136. 
Eusébio, C. and Vieira, A. L. (2013). Destination Attributes' Evaluation, Satisfaction and Behavioural Intentions: A Structural Modelling Approach, International Journal of Tourism Research, 15(1), 66-80.

Garbea, R. V. (2014). Tourist Attractiveness of the Urban Environment in Moldavia, Management and Marketing, 12(1), 84-90.

George, B. P. and George, B. P. (2004). Past Visits and the Intention to Revisit a Destination: Place Attachment as the Mediator and Novelty Seeking as the Moderator, Journal of Tourism Studies, 15(2), 51-66.

Hou, J. S., Lin, C. H. and Morais, D. B. (2005). Antecedents of Attachment to a Cultural Tourism Destination: The Case of Hakka and Non-Hakka Taiwanese Visitors to Pei-Pu, Taiwan, Journal of Travel Research, 44(2), 221-233.

Hui, T.K., Wan, D. and Ho, A. (2007). Tourists' Satisfaction, Recommendation and Revisiting Singapore, Tourism Management, 28(4), 965-975.

Jöreskog, K. G. and Sörbom, D. (1996). LISREL 8: User's Reference Guide, Chicago: Scientific Software International.

Kozak, N., Kozak, M. and Kozak, M. (2009). Genel Turizm - Ilkeler-Kavramlar, Ankara: Detay Publishing.

Mendes, J. C., Valle, P. O., Guerreiro, M. M. and Silva, J. A. (2010). The Tourist Experience: Exploring the Relationship Between Tourist Satisfaction and Destination Loyalty, Tourism: An International Interdisciplinary Journal, 58(2), 111-126.

Oppenheim, A. N. (1966). Questionnaire Design And Attitude Measurement, New York: Basic Books.

Owusu-Frimpong, N., Nwankwo, S., Blankson, C. and Tarnanidis, T. (2013). The Effect of Service Quality and Satisfaction on Destination Attractiveness of Sub-Saharan African Countries: The Case of Ghana, Current Issues in Tourism, 16(7-8), 627-646.

Prayag, G. and Ryan, C. (2012). Antecedents of Tourists' Loyalty to Mauritius: The Role and Influence of Destination Image, Place Attachment, Personal Involvement, and Satisfaction, Journal of Travel Research, 51(3), 342-356.

Ramkissoon, H., Smith, L. D. G. and Kneebone, S. (2014). Visitor Satisfaction and Place Attachment in National Parks, Tourism Analysis, 19(3), 287-300.

Reitsamer, B. F., Brunner-Sperdin, A. and Stokburger-Sauer, N. E. (2016). Destination Attractiveness and Destination Attachment: The Mediating Role of Tourists' Attitude, Tourism Management Perspectives, 19, 93-101. 
Schermelleh-Engel, K., Moosbrugger, H. and Müller, H. (2003). Evaluating the Fit of Structural Equation Models: Tests of Significance and Descriptive Goodness-of-Fit Measures, Methods of Psychological Research Online, 8(2), 23-74.

Schumacker R. E. and Lomax, R. G. (2004). A Beginner's Guide to Structural Equation Modeling, New Jersey: Lawrence Erlbaum Associotes.

Stedman, R. C. (2003). Is it Really Just a Social Construction? The Contribution of The Physical Environment to Sense of Place, Society and Natural Resources, 16(8), 671-85.

Um, S., Chon, K. and Ro, Y. H. (2006). Antecedents of Revisit Intention, Annals of Tourism Research, 33(4), 1141-1158.

Weiermair, K. (2000). Tourist's Perceptions Towards and Satisfaction with Service Quality in the Cross-Cultural Service Encounter: Implications for Hospitality and Tourism Management, Managing Service Quality, 10(6), 397-409.

Williams, D. R. and Vaske, J. J. (2003). The Measurement of Place Attachment: Validity and Generalizability of a Psychometric Approach, Forest Science, 49(6), 830-840.

Yu, L. and Goulden, M. (2006). A Comparative Analysis of International Tourists' Satisfaction in Mongolia. Tourism Management, 27(6), 1331-1342.

Yüksel, A., Yüksel, F. and Bilim, Y. (2010). Destination Attachment: Effects on Customer Satisfaction and Cognitive, Affective and Conative Loyalty, Tourism Management, 31(2), 274-284. 